\title{
CORRECTION OPEN
}

\section{Correction: Insights into the post-translational modification and its emerging role in shaping the tumor microenvironment}

Wen Li, Feifei Li, Xia Zhang, Hui-kuan Lin and Chuan Xu (D)

Signal Transduction and Targeted Therapy (2022)7:31

; https://doi.org/10.1038/s41392-022-00901-7

Correction to: Signal Transduction and Targeted Therapy https:// doi.org/10.1038/s41392-021-00825-8, published online 20 December 2021

After online publication of the article ${ }^{1}$, the authors noticed some of the chemical structures in Fig. 1 are nonstandard forms that need to be corrected. The correct figure is provided as follows. At the same time, an author's name is incorrectly written. The author of "Huikuan Lin" should be "Hui-Kuan Lin". We also noticed a mistake in the sentence "The covalent attachment of glycans to proteins and lipids is called protein glycosylation, which is a common contribution to structure and modification diversity in eukaryotes" in the "O-GlcNAcylation" section of page 6 line 45-47, which should be "The covalent attachment of glycans to proteins is called protein glycosylation, which is a common contribution to structure and modification diversity". The key findings of the article are not affected by these corrections.

The original article has been corrected. 


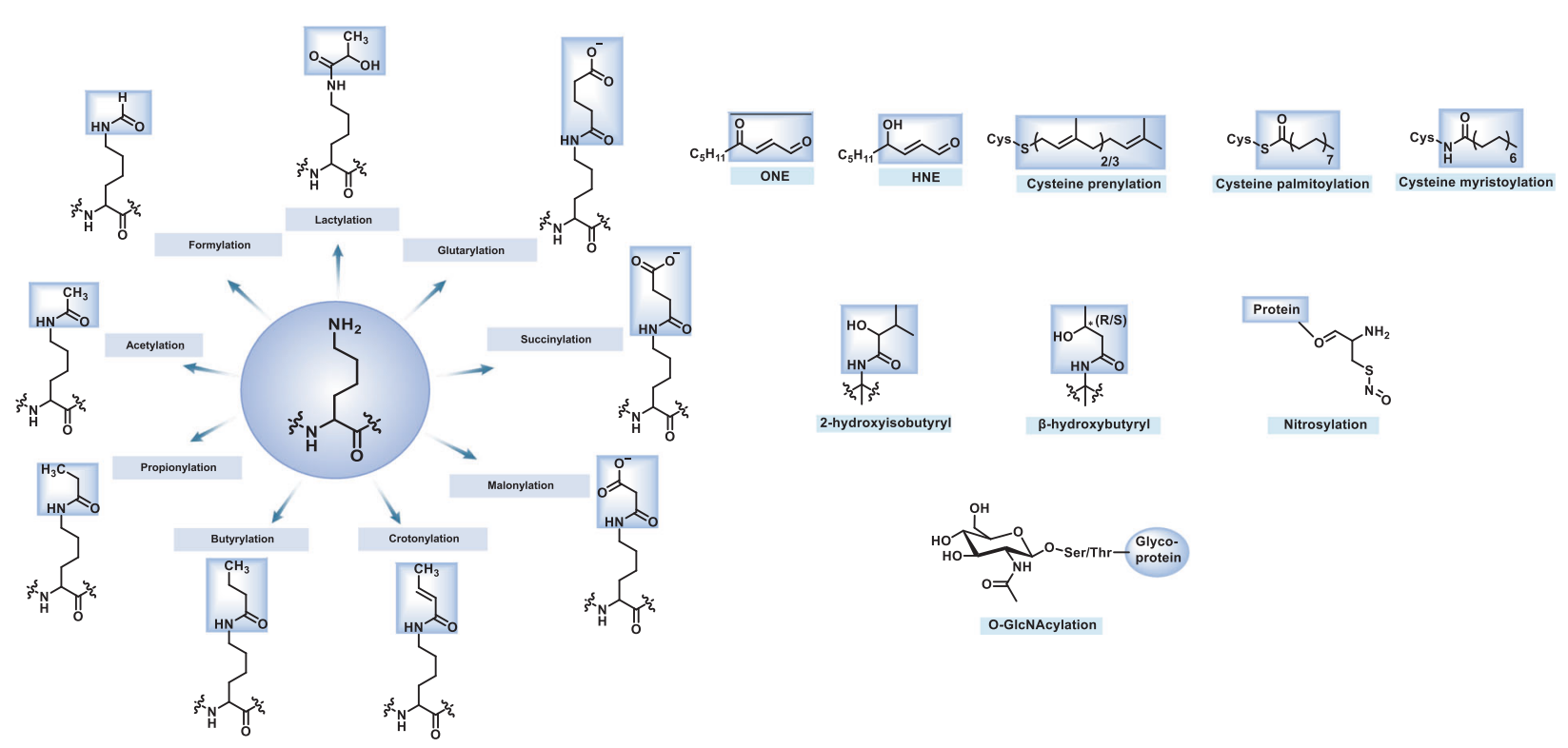

Fig. 1 Chemical structures of histone/non-histone PTMs in this review

\section{REFERENCE}

1. Li, W. et al. Insights into the post-translational modification and its emerging role in shaping the tumor microenvironment. Signal Transduct. Target Ther. 6, 422 (2021).

(c) Open Access This article is licensed under a Creative Commons Attribution 4.0 International License, which permits use, sharing, appropriate credit to the original author(s) and the source, provide a link to the Creative Commons license, and indicate if changes were made. The images or other third party material in this article are included in the article's Creative Commons license, unless indicated otherwise in a credit line to the material. If material is not included in the article's Creative Commons license and your intended use is not permitted by statutory regulation or exceeds the permitted use, you will need to obtain permission directly from the copyright holder. To view a copy of this license, visit http://creativecommons. org/licenses/by/4.0/.

(c) The Author(s) 2022 